The apparent digestibility coefficient (ADC) of dry matter as well as of organic matter, decreased by 5 points between the 6 th and 9 th week of age in the young rabbits. Then it became stable till at least 12 weeks of age. The ADC of nitrogen showed the same variation, but in this case, the reduction of digestibility was 9 to ro points.

By comparison with I I or $\mathbf{I} 2$ weeks old rabbits, the adults digested much better dry matter and organic matter (2-5 points) but the ADC of the crude protein was not significantly different.

As regards crude protein, no modification of the ADC according to the sex was observed as well in young as in adult rabbits. Likewise, no significant difference between Californian and New Zealand adult rabbit was noted concerning the ADC of crude protein. On the other hand, female adults digested better dry matter and organic matter than male adults (2-5 points) and New-Zealand animals showed ADC exceeding by 4 points those obtained with Californians. During growth, we did not observe any effect of sex on the ADC of dry matter and organic matter.

In conclusion, we observed an appreciable decrease in the 3 studied ADC between the 6 th and 9 th of age. As regards dry matter and organic matter, we showed a pronounced effect of sex in the adult and not in the young, and in the adult a difference between New Zealand and Californian rabbits. Lastly, the ADC of nitrogen seems not to be affected either by the sex or by the breed.

\title{
INFLUENCE D'UN TRAITEMENT HYDROTHERMIQUE DE L'ORGE SUR LA DIGESTION DES MATIÈRES AZOTÉES \\ DANS LE RUMEN DE MOUTON : \\ ÉTUDE QUALITATIVE ET QUANTITATIVE \\ AU NIVEAU DE LA CAILLETTE
}

Michelle DURAND, G. VIROBEN et M. BEN AMEUR

Laboratoire de Recherches sur la Conservation et l'efficacité des Aliments,

Centre national de Recherches zootechniques, I. N.R. A., 78350 Jouy en Josas

L'utilisation de l'urée par la microflore du rumen dépend de la présence dans le régime d'une source glucidique rapidement assimilable par les bactéries.

Certains traitements hydrothermiques particuliers, appliqués aux céréales, seraient susceptibles d'augmenter l'accessibilité de leur fraction glucidique aux enzymes bactériennes et, par suite, intensifier la protéosynthèse à partir de l'azote uréique (Durand, r97o; Helmer et al., 1970).

Dans le présent travail, nous avons recherché sur une orge réhumidifiée ( $3^{6} \mathrm{p}$. Ioo d'eau) si un traitement de déshydratation (température de l'air chaud : $145^{\circ} \mathrm{C}$ ) pouvait avoir un effet similaire.

Dans ce but, les répercussions du traitement sur le métabolisme dans le rumen du mouton adulte sont observées par l'étude de la nature et de la quantité des matières azotées transitant au niveau de la caillette (abomasum). Les animaux sont munis d'une fistule simple à ce niveau. Les contenus sont prélevés toutes les 2 heures, sur deux périodes de 24 heures et cumulés pour la. détermination de l'azote total, de l'azote protéique, des acides aminés et de la lignine alimentaire utilisée comme traceur. 
Cette étude a été effectuée, d'une part, en l'absence de supplémentation azotée et, d'autre part, en comparant l'addition d'urée à celle de protéines extraites de soja.

\section{Effet du traitement de l'orge}

Pour l'ensemble des régimes, le traitement thermique élève les teneurs en azote total et protéique des contenus de caillette (tabl. I). La composition en acides aminés de ces contenus révèle, dans ce cas, la présence de protéines d'orge ayant échappé à la désamination bactérienne dans le rumen (augmentation des teneurs en acide glutamique, proline, leucine et arginine).

Pour l'ensemble des régimes traités, les quantités d'éléments azotés récupérées au niveau de la caillette sont, soit supérieures, soit égales aux quantités ingérées (tabl. 2). En particulier, les quantités d'acide aspartique, de thréonine et de lysine sont nettement accrues et traduisent une intensification de la protéosynthèse bactérienne.

Inversement, avec l'orge non traitée on observe des pertes importantes en azote total et protéique, portant principalement sur les acides aminés caractéristiques de la céréale, et témoignant d'un profond remaniement de celle-ci dans le rumen.

\section{Effet de la supplémentation azotée}

La supplémentation azotée, surtout par la protéine de soja, augmente les teneurs des contenus en azote total et protéique mais ne modifie pas significativement leur composition en acides aminés.

Les quantités d'azote total et d'acides aminés transitant au niveau de la caillette sont peu modifiées par l'addition d'urée; par contre, elles sont augmentées par l'addition de protéines extraites de soja.

En conclusion, le traitement appliqué a eu essentiellement deux effets conjugués : une amélioration de la résistance des protéines d'orge à la désamination bactérienne et une modification des fermentations glucidiques au niveau du rumen. Il s'est traduit par une augmentation de la protéosynthèse bactérienne à partir de l'azote ammoniacal d'origine endogène (régime orge seule) ou alimentaire (urée ou soja).

La valeur de l'urée, qui est nettement inférieure à celle de la protéine de soja dans le régime non traité, s'en rapproche lorsque la céréale est déshydratée.

Cependant, les avantages du traitement peuvent être limités par la diminution de la disponibilité et le mauvais équilibre des acides aminés de l'orge qui peuvent entraîner une réduction de l'efficacité azotẹe du régime comme cela a été montré (ZELTER et CharLET-LERY, 1972). Une étude de la nature et de la quantité des acides aminés absorbés au niveau intestinal devrait permettre de conclure définitivement sur l'intérêt de ce type de traitement.

\section{RÉFÉRENCES BIBL,IOGRAPHIQUES}

Durand M., 1970. Influence du traitement technologique de l'aliment énergétique (orge immature) sur le métabolisme de ses glucides et de l'urée dans le rumen du mouton. C. R. Acad. Sci. Paris, 271, $2167-21$ 7o, série D.

Helmer L. G., Barteey E. E., Deyoe C. W., Meyer R. M., Pfost H. B., r97o. Feed Processing. $V$. Effect of an expansion-processed mixture of grain and urea (Starea) on nitrogen utilization in vitro. J. Dairy Sci., 53, 330-335.

Zelter S. Z., Charlet-Lery G., 1972. Influence du traitement hydrothermique d'une orge immature ou mûre réhydratée, sur sa valeur alimentaire et celle de l'urée ajoutée, chez le jeune taurillon. Ann. Zootech., 21, 332-345. 

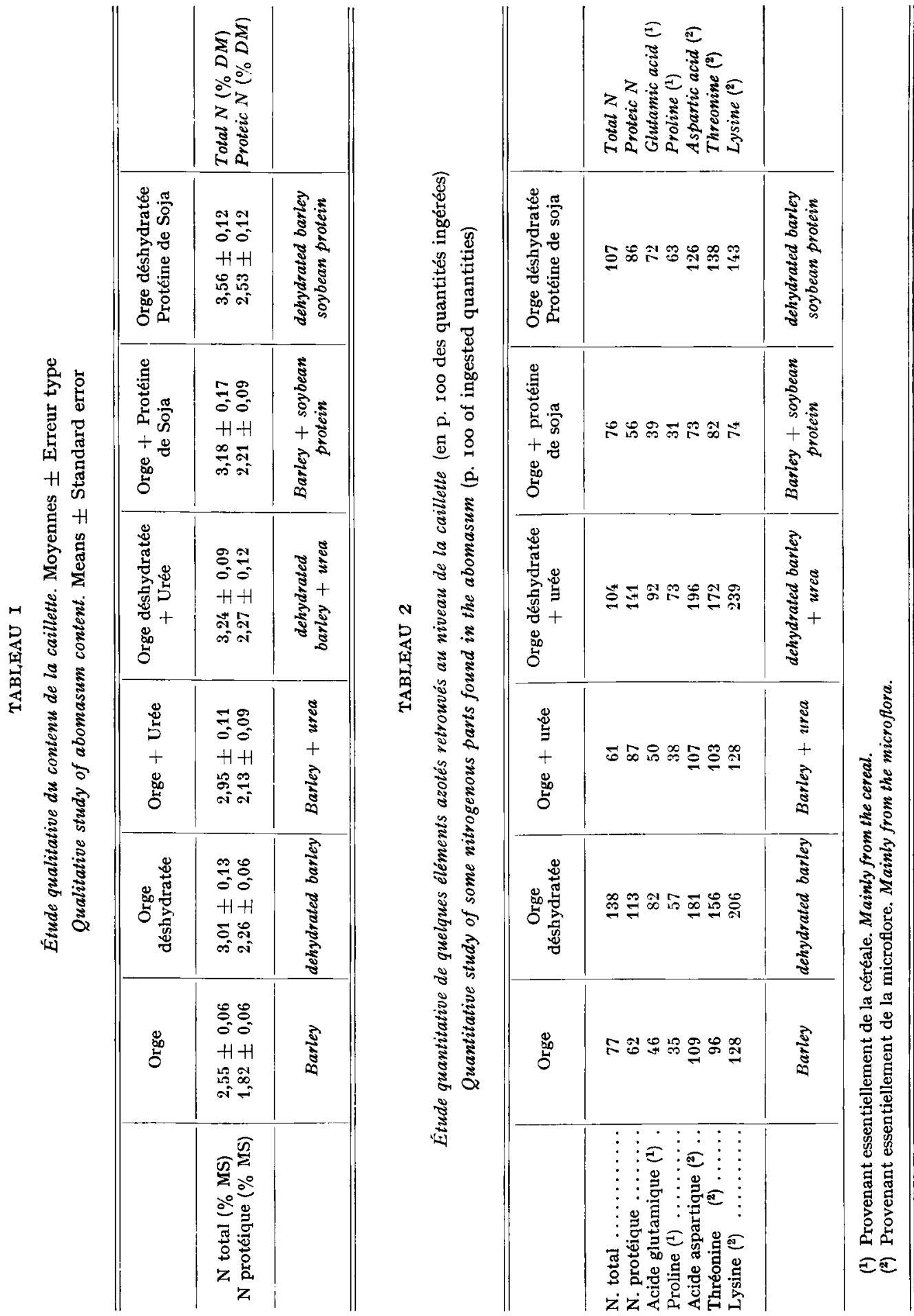


\section{SUMMARY}

\section{EFFECT OF HEAT-MOISTURE TREATMENT OF BARLEY ON THE DIGESTION OF NITROGENOUS COMPOUNDS IN THE RUMEN OF SHEEP : QUALITATIVE AND QUANTITATIVE STUDY AT THE LEVEL OF THE ABOMASUM}

Utilization of $\mathrm{N}$-urea by rumen bacteria depends on the quantity of quickly available carbohydrates present in ruminant diets.

Some heat-moisture treatments of cereals could increase the availability of carbohydrates to enzymatic digestion and therefore, improve bacterial synthesis of proteins from $\mathrm{N}$-urea (Durand, 1970) ; (Helmer and coll., 1970).

In the present work, we studied whether the same effect could be observed with barley soaked in water ( $36 \mathrm{p}$. 100 moisture) and then dried in warm air at $145^{\circ} \mathrm{C}(30 \mathrm{mn})$.

The influence of this treatment on nitrogen metabolism in the rumen of sheep was investigated by studying the type and amount of nitrogenous compounds flowing through the abomasum.

The animals were fitted with a single cannula at this level.

During a 24 hours period, $50 \mathrm{ml}$ samples of abomasal contents were withdrawn every 2 hours and pooled for the measurements of total and protein nitrogen, amino acids and dietary lignin used as a tracer.

Rations without supplementary $\mathrm{N}$ were compared with rations containing either urea or soyabean protein.

\section{Effect of barley treatment}

For all diets, the treatment increased total and protein nitrogen of the abomasum contents (table I). The increase of glutamic acid, proline, leucine and arginine indicated that part of the treated barley protein had not been deaminated in the rumen.

For all the treated diets, the amounts of nitrogen compounds found in the abomasum were either the same or greater than the amounts that were ingested (table 2). An increase of aspartic acid, threonine and lysine indicated improved bacterial proteosynthesis.

On the other hand, with untreated barley, large losses of total and protein nitrogen were observed, and especially significant losses of amino acids from barley (Glu, Pro, Leu, Arg) after passage through the rumen.

\section{Effect of nitrogen supplementation}

Nitrogen supplementation, especially by soyabean protein, increased total and protein nitrogen of the contents, without significant alteration of their amino acid composition.

Amounts of total nitrogen and amino acids flowing through the abomasum were little changed by urea supplement, but they increased when soyabean protein was fed.

In conclusion, the treatment of barley caused two interrelated changes : improvement of resistance of barley protein to bacterial deamination and modification of carbohydrate fermentations in the rumen.

When no supplementary $N$ was fed, it resulted in less deamination of barley proteins ; yet, more bacterial protein was synthesized, probably from endogenous sources of $\mathrm{N}$. 
In the presence of urea or soyabean protein, bacterial protein synthesis was further increased.

With untreated barley, urea was less efficient than soyabean for this synthesis, but approached soyabean value when the barley was treated.

The decreased $\mathrm{N}$ efficiency of the diet (ZeLTER and CharLet-Lery, 1972) probably arising from the lower availability could limit the benefits of the barley treatment observed at the abomasum level. A study of the nature and amount of amino acids absorbed at the gut level could allow to decide whether this treatment is adequate.

\title{
DIGESTION DES PROTÉINES DE CÉRÉALES CHEZ L'AGNEAU EN CROISSANCE
}

\author{
R. PION, C. CHAMPREDON et P. THIVEND * \\ Laboratoire d'études du Métabolisme azoté, \\ * Station de Recherches sur l'Élevage des Ruminants, \\ Centre de Recherches de Clermont Ferrand, I. N. R. A., \\ Theix 63110 Beaumont
}

Nous avons étudié la composition des contenus digestifs d'agneaux en croissance ayant reçu des régimes comportant diverses céréales (VERMorel et al., 1970).

Des échantillons moyens de contenus de caillette et de gros intestin prélevés à l'abattage sont constitués à partir de trois lots d'animaux ayant reçu des régimes renfermant respectivement du maiss, du blé et de l'orge ; les céréales représentaient environ 70 p. Ioo des régimes, qui comportaient en outre environ $20 \mathrm{p}$, Ioo de farine de luzerne et du tourteau de soja.

Les matières azotées hydrosolubles sont extraites après neutralisation, et séparées des résidus par centrifugation ( $35000 \mathrm{~g}, \mathrm{I} \mathrm{h}$ ). Les résidus subissent une extraction par l'éthanol $60 \mathrm{p}$. roo, puis par l'acide trichloracétique à ıo p. Ioo (ATC). Les extraits aqueux sont analysés par filtration sur gel Sephadex G 25 ; les différents pics sont localisés par l'enregistrement de l'absorption à $280 \mathrm{~m} \mu$ et par la détection des $\mathrm{NH}_{2}$ libres par réaction avec la ninhydrine. Les acides aminés des différentes fractions sont dosés par chromatographie sur colonne.

Des échantillons des céréales utilisées pour la constitution des régimes sont analysés dans les mêmes conditions, après avoir été mis en suspension dans une solution d'HCl diluée, de manière à les amener à un $\mathrm{pH}$ voisin de celui des contenus de caillette.

Dans ces conditions, l'extraction éthanolique n'a pas solubilisé la totalité des prolamines des céréales, puisque les extraits obtenus ne renferment que de I 8 à $25 \mathrm{p}$. Ioo des matières azotées des graines. C'est pourquoi nous avons comparé les résultats obtenus sur les contenus digestifs à ceux de ces analyses, et non à la composition en protéines des céréales étudiées.

Les compositions en acides aminés des résidus d'extraction permettent de supposer qu'une partie au moins des prolamines qui ne sont pas extraites par l'alcool se trouve dans les résidus d'extraction, au moins dans le cas du mais.

Une partie de leurs acides aminés peut se trouver sous forme libre ou dans des peptides plus ou moins longs dans les extraits aqueux, ainsi qu'en témoigne la teneur élevée en leucine par rapport à celle de l'extrait aqueux de maïs de la fraction hydrosoluble des contenus de caillette des animaux ayant consommé cette céréale. La comparaison des teneurs en lysine de ces deux extraits ne permet pas d'aboutir à la même conclusion en ce qui concerne cet acide aminé. 